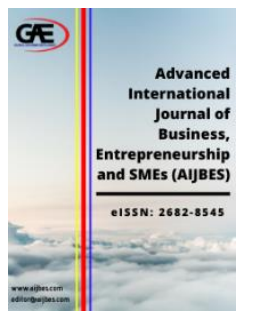

\author{
ADVANCED INTERNATIONAL JOURNAL OF \\ BUSINESS, ENTREPRENEURSHIP AND SMES \\ (AIJBES) \\ WWW.aijbes.com
}

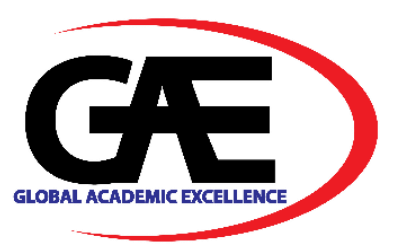

\title{
COVID 19: GOVERNMENT RESPONSES TO OIL PRICE
}

\author{
Chia-Guan $\mathrm{Keh}^{1}$, Yan-Teng Tan ${ }^{2 *}$, Siu-Eng Tang ${ }^{3}$ \\ 1 Department of Economics, Universiti Tunku Abdul Rahman, Malaysia \\ Email: kehcg@utar.edu.my \\ 2 Department of Economics, Universiti Tunku Abdul Rahman, Malaysia \\ Email: tyteng@utar.edu.my \\ 3 Department of Economics, Universiti Tunku Abdul Rahman, Malaysia \\ Email: tangse@utar.edu.my \\ * Corresponding Author
}

\section{Article Info:}

\section{Article history:}

Received date:08.12.2020

Revised date: 04.01.2021

Accepted date: 10.01.2021

Published date: 01.03.2021

\section{To cite this document:}

Keh, C. G., Tan, Y. T., \& Tang, S. E. (2021). Covid 19: Government Responses To Oil Price. Advanced International Journal of Business, Entrepreneurship and SMEs, 3 (7), 0109.

DOI: $10.35631 / A I J B E S .37001$.

This work is licensed under $\underline{\text { CC BY 4.0 }}$

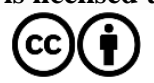

\begin{abstract}
:
The outbreak of the coronavirus (COVID-19) has aroused global interest and it had a significant impact on the global economy. The majority of the countries have implemented lockdown regulations and social distancing policies to prevent the spread of COVID-19, which has an unprecedented impact on the oil and gas market. Hence, this scenario motivated us to study how government responses aimed at banning the spread of COVID-19 affect oil prices? To answer this question, this study examines the Movement Control Order imposed by the government to responses the oil prices in Malaysia. The study emphasizes the period from the start of January 2020 to July 2020 when the coronavirus began spreading into Malaysia. We empirically investigate the impact of government responses on both BRENT and WTI's oil prices. The findings report that the additional one-day stay at home requirements cause a reduction of $29 \%$ and $37 \%$ in the closing price for BRENT and WTI's oil prices respectively. Workplace closing results in a $5.7 \%$ and $14.3 \%$ reduction in the closing price for BRENT and WTI correspondingly. In contrast, international travel controls, restrictions on gatherings, and debt or contract relief for households have a positive relationship with both oil prices of BRENT and WTI. The results of this study might assist the government and investors to understand the impact of Malaysia's government responses to COVID-19 on oil prices.
\end{abstract}

\section{Keywords:}

Government Responses, COVID-19, Oil Prices, Malaysia 


\section{Introduction}

The worldwide economy is confronting the two severe stuns which are the spread of the novel COVID-19 pandemic and the ongoing low oil prices (Sharif, Aloui, \& Yarovaya, 2020). The mix of these two issues also trouble the economy of Malaysia and it would probably drive the economy into the downturn. In the early of February, Malaysian government was unprepared to tackle the coronavirus when Malaysian first tested positive for COVID-19 (Shah et al., 2020). Malaysia government took several steps to relieve the panic in public only after the first two deaths were reported in March (Majid, 2020). Subsequently, a Movement Control Order (MCO) was implemented to restrict the people move into or out of an area and it would assist to control the spread of the coronavirus. This move is important as the number of positive COVID-19 cases could be reduced by isolating infected people and practicing the social distancing policy (WHO, 2020). Besides, a number of policy was implemented such as international travel control, restrictions on gatherings, stay at home requirement and workplace closing in order to prevent the spread of the coronavirus disease.

In addition, the MCO and international travel control have led to demand shocks in the oil market. As compared to last year, the global oil demand fell to 19.9 million barrels per day in April 2020 (IEA, 2020). Starting from the second quarter of 2020, the global oil demand is projected to slowly recover. During the pandemic, demand of the oil reduced while the supply increased due to majority of the economy activities had ceased. As a result, BRENT oil prices dropped since mid-march from \$50USD to \$20USD while WTI oil price dropped to negative $\$ 37.63$ USD on 20 April $2020^{1}$, for the first time in history (Figure 1). This makes the oil investors tremble and loss of confidence (Mensi, Sensoy \& Kang, 2020). Besides, Malaysia's economic growth is projected to decrease severely by $3.1 \%$ in 2020 due to the impact of the policy responses implemented to prevent the spread of COVID-19 (World Bank, 2020). Obviously, the global uncertainty surrounding the COVID-19 eruption has severely hampered the dynamics of crude oil price (Mensi et al., 2020). Some of the economists believe that the oil market could be saved by the OPEC or those led-oil producers, but what is particularly worrisome is that the short term and long term policies in coping the COVID-19 would make the oil market collapse (Sharif, Aloui \& Yarovaya, 2020). As a result, our study aims to examine the impact of the government policies to the oil prices.

\section{Figure 1: Oil Prices from 27 January to 10 July 2020}

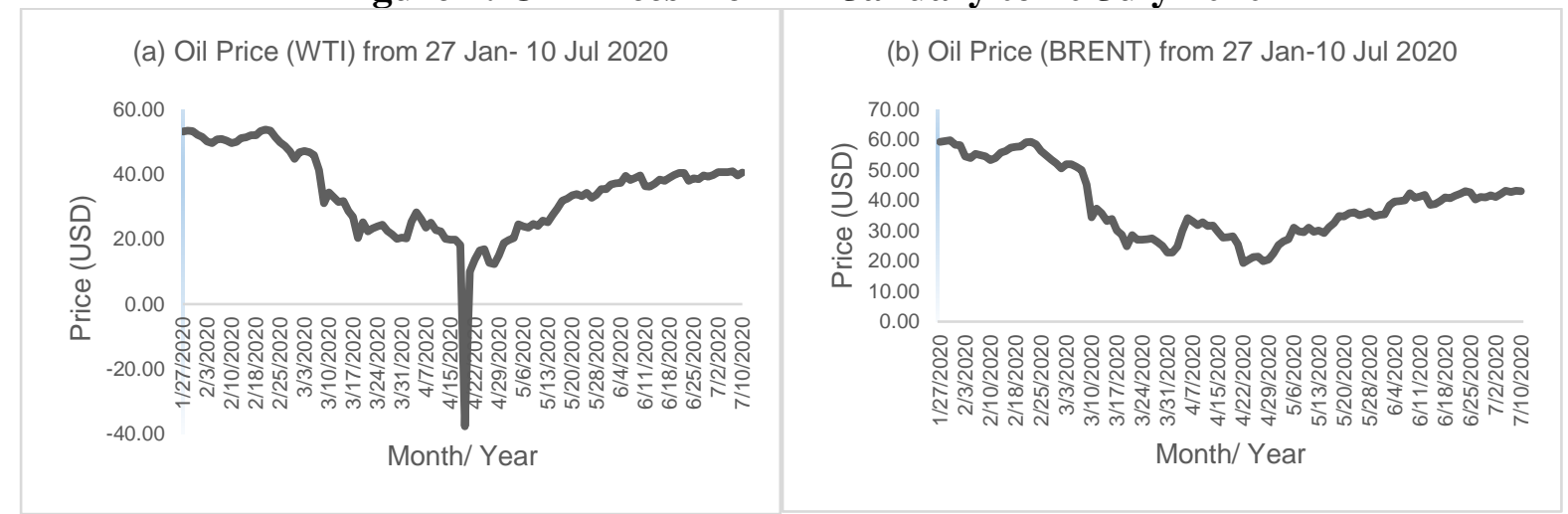

Source: Business Insider, 2020

\footnotetext{
1 Organisation of Petroleum Exporting Countries (OPEC) used the Brent crude price as an international benchmark price. On the other hand, WTI crude price is a benchmark for United State oil prices. 


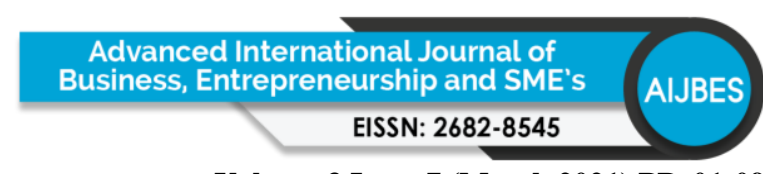

Volume 3 Issue 7 (March 2021) PP. 01-09

DOI 10.35631/AIJBES.37001

The domestic economy in Malaysia is also affected by the fluctuation of global crude oil as the country is heavily dependent on oil revenue. The country is one of the significant oil-exporting country in Southeast Asia. Any sudden and unexpected shocks would change the oil price and its production (Akpan, 2009); economic growth would be instable if there is an inconsistent oil fluctuation (Olomola, 2006). Since the Malaysia is overwhelming rely on the oil income, its economies fluctuate with changes in global crude oil prices due to the COVID-19 pandemic. The oil revenue collected by the government was RM38 billion, which was the 2.8 percent to the GDP of Malaysia in 2018 (Department of Statistic, 2020). However, the national oil income is expected to lose billions of ringgits if the oil prices keep staying low at \$30USD (Figure 1) for more than 3 months due to the spread of COVID-19 (Lim, 2020).

The unexpected outbreak of the epidemic changed the balance in the oil and gas industry. To respond to the pandemic, firms force to keep interaction with their dealers, suppliers, and other stakeholders to ensure that the business continues in the short term. The firm needs to reorganize its operating model and modify its cost structure during the lockdown period. The aforementioned policies have significantly led to social distress around the world and huge economic interruption (OECD, 2020). Most of the employees are work from home, some of the workers are laid-off (Shah, et al., 2020) and some of them took unpaid leave (Karim, Haque, Anis \& Ulfy, 2020). In line with this, government provides income support to those households with financial difficulties and income disruption due to the MCO and coronavirus outbreak. Besides, government is freezing financial obligation for households such as delaying or stopping loan repayment. As a result, this study also includes the non-social distancing policy such as debt/contract relief and income support for households as the control variables.

In conclusion, this study complements the research on the impact of government responses to fluctuation of the oil price during the COVID-19 pandemic. It is also served as a guidance for the policy makers and market participants in the field of designing policy and investment portfolio respectively. The remainder of the paper is organized as follow: literature review, data and methodology and discussion of the results. Lastly, conclusion is made.

\section{Literature Review}

The outbreak of Covid-19 has reduced significantly the demand of crude oil and causing an unprecedented low level of oil price (Ajami, 2020). In this regard, recent literature surveys by Sharif et al. (2020) suggest that movement control and stunted production in both China and European countries due to the pandemic are the two major reasons that resulting in unstable oil price through the demand side. While Musa et al. (2020) and Albulescu (2020) investigate the impacts of COVID-19 pandemic on crude oil price using ARDL model in both short and long run. Their studies concluded that the pandemic has significant negative effect on the oil price in both short and long run. Norouzi, Zarazua, Choubanpishehzafar and Enevoldsen (2020) developed a comparative regressive and neural network model to analyse the implication of the pandemic on the demand of electricity and petroleum in China. The results show that number of infected has a significant impact on energy demand.

Quarantine polices affect the manufacturing, transportation and tourism sectors significantly in most of the advanced economies. Besides, industrial production reduces in Europe has caused oil price adversely affected (Kingsly \& Kouam, 2020). Border closure reducing the number of tourist and making the bulk of oil demand reliant on the logistic sector. Oil supply more than demand has placed the pressure on oil prices. In line with this, Russia and Saudi Arabia has agreed to reduce the oil supply to cushion the oil price pressure. Meanwhile, the price of all Copyright $\odot$ GLOBAL ACADEMIC EXCELLENCE (M) SDN BHD - All rights reserved 
Volume 3 Issue 7 (March 2021) PP. 01-09

DOI 10.35631/AIJBES.37001

types of fuel from gasoline to diesel has fallen due to quarantine measures by reducing the industrial production. As the coronavirus spread across the regions, oil prices will likely remain under pressure (Kingsly \& Kouam, 2020).

Besides, many studies have been focusing on the impact of government intervention on stock market return and economy activities in general but not the oil market (Baker, Bloom, Davis, Kost, Sammon, \& Viratyosin, 2020, Ashraf, 2020, Zaremba, Kizys, Aharon, \& Demir, 2020). In regards of the stock market return, Baker et al. (2020) suggests that COVID-19 has unprecedented effect on the U.S stock market mainly due to the government intervention on business activity and non-mandatory social distancing, operating with sturdy effects in a service oriented economy. Ashraf (2020) further found that the impact on the stock market return react differently towards the announcements of government. Announcement regarding social distancing manoeuvres have a direct negative effect while public consciousness schemes, testing and quarantining policies, and income support packages mostly affect the return positively. Based on a study of 67 countries, Zaremba et al. (2020) suggest that government interventions especially awareness campaigns and withdrawal of communal gathering, have positive and significant effect on the fluctuation in the equity market. In general, covid-19 intensify the volatility of the equity market and the impacts are varied by different measurements taken by the government.

As for the impact on economy and business activities, Koren and Peto (2020) argued that the social distancing can be inimical to the economy as most of the business activities rely heavily on face to face communication. Their result suggests that a $12 \%$ wage subsidy is needed to recoup for the interruption of the communication when the business are forced to reduce employee contacts by half. Strong and Welburn (2020) suggest that $73 \%$ of the household would experience certain decrease in the income due to Covid-19. Akter (2020) examine the effect of Covid-19 on food price. The results show that overall food price increases by $1 \%$ in March 2020 as compared to January and February 2020, following the stay-at-home restrictions. Food prices and stay-at-home constraint were significantly corresponded after controlling for inter-state dissimilarities in COVID-19 affectedness and other cushioning and adjustment measures, such as international travel limitations, road closures and the dimension of the economic stimulus packages.

In short, majority of previous researches focus on the effect the COVID-19 on stock market and economics or business activities (Baker, et al., 2020; Ashraf, 2020; Zaremba, et al., 2020; Koren \& Peto, 2020, Strong \& Welburn, 2020; Akter, 2020). However, studies were niched when it comes to relate the pandemic with oil price, especially for the case of Malaysia.

This is the study gap that we would like to fill up and shed some light on. Hence, our study offers two important contributions to the existing literatures. Firstly, we enhance the emerging literature which assess the aftermath of COVID-19 on petrol industry. Secondly, we complement the recent studies which investigate the implications of government interventions targeted at banning the spread of COVID-19 on oil industry.

\section{Data and Methodology}

\section{Data}

In this section, we investigate the relationship between Movement Control Order and closing oil price for BRENT and WTI during COVID 19 period. Movement Control Order denoted as preventive movement measure implemented by government of Malaysia to control the Copyright (C) GLOBAL ACADEMIC EXCELLENCE (M) SDN BHD - All rights reserved 
Volume 3 Issue 7 (March 2021) PP. 01-09 DOI 10.35631/AIJBES.37001

movement of people cross the borders or states in order to reduce the spreading of the COVID19 pandemic in the country. In line with this Movement Control Order implementation, it will reduce the demand of the oil consumption due to the control movement of people and eventually decreasing the oil price. The data collection is from $27^{\text {th }}$ January to $10^{\text {th }}$ July 2020 , which the total observation is 116 . In respect to dependent variables, the oil price is proxied by the closing price for BRENT (LCPBRENT) and WTI (LCPWTI). To mitigate the observed skewness, both closing oil prices are expressed in natural logarithm. The BRENT crude (BRENT) can be defined as the North Sea's oil fields that is located in between the Norway and Shetland Islands whereas oil fields mainly from North Dakota, Texas and Louisiana of United States can be named as West Texas Intermediate (WTI) (Energy Information Administration, 2017). BRENT crude is used by two thirds of all oil pricing as a yardstick where considered as most oil priced and popular (Energy Information Administration, 2012). On the other hand, numerous of traders are considered that WTI is an important yardstick as compared to BRENT as the production of WTI is keep increasing (Energy Information Administration, 2020).

In respect to independent variables, the Movement Control Order are represented by international travel control (IT), restrictions on gatherings (ROG), stay at home requirement (SAHR) and workplace closing (WPC). Moreover, we control for the debt or contract relief for households (DCR) where government is freezing financial obligation for households such as delaying or stopping loan repayment or water services. Income support (IS) is the initiative of government to allocate cash assistant to individual who is retrenched from their company or unable to work. Besides, the number of COVID-19 positive confirmed cases (LCC) is also added. The LCC variable is transformed into natural logarithm.

\section{Model Specification}

In this study, we estimated with a least square regression by applying multivariate model as shown below:

$$
\begin{aligned}
& L C P B R E N T_{t}=c+L C C_{t}+I T_{t}+S A H R_{t}+R O G_{t}+W P C_{t}+I S_{t}+D C R_{t}+\varepsilon_{t} \\
& L C P W T I_{t}=c+L C C_{t}+I T_{t}+S A H R_{t}+R O G_{t}+W P C_{t}+I S_{t}+D C R_{t}+\varepsilon_{t}
\end{aligned}
$$

Where LCPBRENT is natural log vector of closing price for BRENT, LCPWTI is natural log vector of closing price for WTI. LCC is natural log vector of number of COVID-19 positive confirmed cases, IT is international travel control, SAHR is stay at home requirement, ROG is restrictions on gatherings, WPC is workplace closing, IS is income support and DCR is debt or contract relief for households. $\varepsilon_{t}$ is an error term which is assumed to be normally distributed and subscript $t_{t}$ is business day of the week.

Table 1: The Impact of Movement Control Order on Closing Oil Price for BRENT and WTI

\begin{tabular}{l|c|c}
\hline \multirow{3}{*}{ Variables } & $(1)$ & $(2)$ \\
\cline { 2 - 3 } & Closing Price for BRENT & Closing Price for WTI \\
\cline { 2 - 3 } & (LCPBRENT) & (LCPWTI) \\
\hline \multirow{2}{*}{ LCC } & $-0.12429 * * *$ & $-0.0959^{* * *}$ \\
& $(-5.0786)$ & $(-2.7353)$ \\
\hline IT & $0.05309^{* *}$ & 0.0631
\end{tabular}


Volume 3 Issue 7 (March 2021) PP. 01-09

DOI 10.35631/AIJBES.37001

\begin{tabular}{l|c|c} 
& $(1.9920)$ & $(1.6554)$ \\
\hline SAHR & $-0.286217 * * *$ & $-0.3754 * *$ \\
& $(-6.0715)$ & $(-5.5675)$ \\
\hline ROG & $0.09368^{* *}$ & $0.1619 * * *$ \\
& $(2.30229)$ & $(2.7821)$ \\
\hline WPC & $-0.05708^{*}$ & $-0.1431^{* * *}$ \\
& $(-1.8398)$ & $(-3.2113)$ \\
\hline IS & 0.0804 & -0.0258 \\
& $(0.8776)$ & $(-0.1968)$ \\
\hline DCR & $0.1544 * * *$ & $0.1461 * *$ \\
& $(3.1290)$ & $3.0707)$ \\
\hline C & $4.1732 * * *$ & $(29.8615)$ \\
& $(45.0421)$ & 0.7131 \\
\hline R-squared & 0.7739 & 0.6943 \\
\hline Adjusted R-squared & 0.7593 & 116 \\
\hline Observation & 116 & 1
\end{tabular}

Notes: LCC $=$ the number of COVID-19 positive confirmed cases in natural logarithm. IT $=$ International Travel controls. SAHR $=$ Stay at home requirements. $\mathrm{ROG}=$ Restrictions on gatherings. WPC $=$ Workplace closing. IS $=$ Income support for households. $\mathrm{DCR}=$ Debt/contract relief for households. $\mathrm{C}=$ Intercept. $\mathrm{LCPBRENT}=$ natural logarithm of the closing price oil for Brent in USD. LCPWTI = natural logarithm of the closing price oil for WTI in USD. $* * *, * *, *$ represent the $1 \%, 5 \%$ and $10 \%$ level of significance. The parenthesis is represented by Tstatistic.

\section{Discussion of Results}

The results are presented in Table 1. Based on the results, the column 1 and 2 reveals that there have significant and negative relations of LCC coefficient and this shows that the number of confirmed positive COVID-19 cases significantly affected the closing oil price for BRENT and WTI. The $1 \%$ increase in the number of COVID-19 positive confirmed cases led to decrease $0.12 \%$ and $0.09 \%$ in the closing price for BRENT and WTI respectively. The international travel control is positive and significantly related to closing price for BRENT. Furthermore, the SAHR and WPC coefficient are negative and significantly related to column (1) and (2). This means that stay at home requirement and workplace closing had a significant and negative effect on closing price for BRENT and WTI. An additional one day stay at home requirements caused a reduction of $29 \%$ and $37 \%$ on the closing price of BRENT and WTI respectively. In addition, workplace closing results a $5.7 \%$ and $14.3 \%$ drop in the closing price for BRENT and WTI correspondingly. On the other hand, ROG coefficient is positive and significant related to both column (1) and (2). This indicates that imposed restriction of gathering has a positive and significant effect on both closing price for BRENT and WTI. Moreover, government provided debt or contract relief for households (DCR) has positive and significant relationship with both closing price for BRENT and WTI. This showed that debt or contract relief for households increased by $1 \%$, the closing price for BRENT and WTI increased by $0.15 \%$ and $0.146 \%$ respectively.

\section{Conclusion}

This study examines the Movement Control Order imposed by government to responses the oil prices in Malaysia due to the spread of COVID pandemic. Policy makers were under pressure to respond to the outbreak of this coronavirus as oil price is considered one of the important sources contributed to the government's revenue in Malaysia. Thus, government imposed Movement Control Order that had far reaching negative and positive effects on the oil prices. 
Volume 3 Issue 7 (March 2021) PP. 01-09

DOI 10.35631/AIJBES.37001

The findings report that the number of COVID-19 positive confirmed cases, stay at home requirements and workplace closing negatively affected the both oil prices of BRENT and WTI. On the other hand, international travel controls, restrictions on gatherings and debt or contract relief for households has positive relationship with both oil prices of BRENT and WTI.

The collapse in oil price due to the COVID-19 shock which has a significant impact on the economy through decreasing export and government revenue. Subsequently, this shock would double the size of the deficit and increase the government debt in the absence of fiscal consolidation. The authority should respond to the health emergency and the risk of recession. It is suggested that the authorities should delay the fiscal consolidation of the continuing decline in oil prices until recovery from the epidemic. On the other hand, authorities should increase the health expenditure in adding the medical equipment and infrastructure, deploying the vaccine for the residents. The authorities should also use targeted approach towards households and SMEs most badly affected (Arezki \& Nguyen, 2020). Besides, to deal with the COVID-19 shock, the authorities should modify their response to the severity of the shocks in order to save the economy and oil prices.

In conclusion, there is some limitation in this study. The core limitation of this paper is applying short time period due to limited dataset. It is suggested that future study may extend the study period of coronavirus crisis to capture the response of government Movement Control Order or other social distancing policies in the long term. Moreover, future study can explore the impact on government policy on different perspective such as stock market or social media.

\section{References}

Ajami, R. (2020). Globalization, the Challenge of COVID-19 and Oil Price Uncertainty. Journal of Asia-Pacific Business, 21(2).

Akpan, E. O. (2009, March). Oil price shocks and Nigeria's Macroeconomy. In A Paper Presented at the Annual Conference of CSAE Conference, Economic Development in Africa, March (pp. 22-24).

Akter, S. (2020). The impact of COVID-19 related 'stay-at-home'restrictions on food prices in Europe: findings from a preliminary analysis. Food Security, 12(4), 719-725.

Albulescu, C. (2020) Coronavirus and Oil Price Crash. Available at SSRN: https://ssrn.com/abstract=3553452 or http://dx.doi.org/10.2139/ssrn.3553452

Arezki, R., \& Nguyen, H. (2020). Coping with a Dual Shock: COVID-19 and Oil Prices. Economics in the Time of COVID-19. CEPR Press VoxEU. org eBook.

Ashraf, B. N. (2020). Economic impact of government interventions during the COVID-19 pandemic: International evidence from financial markets, Journal of Behavioral and Experimental Finance, 27, 100371.

Baker, S., Bloom, N., Davis, S., Kost, Kyle J., Sammon, Marco C. \& Viratyosin, T. (2020), The Unprecedented Stock Market Impact of COVID-19, No 26945, NBER Working Papers, National Bureau of Economic Research, Inc,

Business Insider (2020). Retrieved from https://markets.businessinsider.com/commodities/historical-prices/oil-price

Department of Statistic. (2020). Gross domestic product (GDP) from the palm oil industry in Malaysia from 2011 to 2018. Retrieved from https://www.statista.com/statistics/952715/malaysia-gdp-from-palm oilindustry/\#: :text=In\%202018\%2C\%20the\%20gross\%20domestic,the\%20total\%20 GDP\%20of\%20Malaysia. 
Volume 3 Issue 7 (March 2021) PP. 01-09 DOI 10.35631/AIJBES.37001

Energy Information Administration (2012). Drop in U.S. Gasoline Prices Reflects Decline in Crude Oil Costs. $\quad$ Retrieved https://www.eia.gov/todayinenergy/detail.php?id=6850

Energy Information Administration (2017). Another Type of Crude Oil to Be Included in Calculation of the Brent Price Benchmark. Retrieved from https://www.eia.gov/todayinenergy/detail.php?id=30292

Energy Information Administration (2020). Short-Term Energy Outlook: Crude Oil. Retrieved from https://www.eia.gov/outlooks/steo/marketreview/crude.php

International Energy Agency. (2020). Oil Market Report. Retrieved from https://www.iea.org/reports/oil-market-report-april-2020

Karim, W., Haque, A., Anis, Z., \& Ulfy, M. A. (2020). The movement control order (mco) for covid-19 crisis and its impact on tourism and hospitality sector in malaysia. International Tourism and Hopitality Yournal, 3(2), 1-7.

Koren, M., \& Peto, R. (2020). "Business disruptions from social distancing." Covid Economics: Vetted and Real-Time Papers, 1(2), 13-31.

Kingsly, K \& Kouam, H., (2020). Heterogeneity of COVID-19 effects and implications for global commodity prices in the medium-term. COVID-19 - Research note. Developing Economies. SSRN Electronic Journal. DOI: 10.2139/ssrn.3555880

Lim, J. (2020). Oil slump not good for nation's coffers. Retrieved from https://www.theedgemarkets.com/article/oil-slump-not-good-nations-coffers

Majid M. (2020). Covid-19: panic and the Malaysian economy. New Straits Times. Retrieved from https://www.nst.com.my/opinion/columnists/2020/03/575187/covid-19-panicand-malaysian-economy

Mensi, W., Sensoy, A., Vo, X. V., \& Kang, S. H. (2020). Impact of COVID-19 outbreak on asymmetric multifractality of gold and oil prices. Resources Policy, 101829.

Musa, K. S., Maijama'a, R., Mohammed, N. \& Yakubu, M. (2020). COVID-19 Pandemic, Oil Price Slump and Food Crisis Nexus: An Application of ARDL Approach. Open Access Library Journal, 7, e6403. doi: http://dx.doi.org/10.4236/oalib.1106403.

Norouzi, N., Zarazua de Rubens, G., Choubanpishehzafar, S., \& Enevoldsen, P. (2020). When pandemics impact economies and climate change: Exploring the impacts of COVID-19 on oil and electricity demand in China, Energy Research \& Social Science, 68, 101654, ISSN 2214-6296.

OECD (2020). New OECD outlook on global economy. Retrieved from https://www.oecd.org/coronavirus/en/

Olomola, P. (2006). Oil price shocks and aggregate economic activity in Nigeria. African Economic and Business Review, 4(2), 40- 45.

Shah, A. U. M., Safri, S. N. A., Thevadas, R., Noordin, N. K., Abd Rahman, A., Sekawi, Z., ... \& Sultan, M. T. H. (2020). COVID-19 Outbreak in Malaysia: Actions Taken by the Malaysian Government. International Journal of Infectious Diseases.

Sharif, A., Aloui, C., \& Yarovaya, L. (2020). COVID-19 pandemic, oil prices, stock market, geopolitical risk and policy uncertainty nexus in the US economy: Fresh evidence from the wavelet-based approach. International Review of Financial Analysis, 101496.

Strong, A. \& Welburn, J. W. (2020). An Estimation of the Economic Costs of Social Distancing Policies, Research Report RR-A173-1, RAND Corporation.

World Bank (2020). Malaysia Economic Monitor: Surviving the Storm (June, 2020). Washington, DC. World Bank.

World Health Organization. (2020). Coronavirus disease 2019 (COVID-19) situation report44. 2020 Retrieved from https://www.who.int/docs/default 
Volume 3 Issue 7 (March 2021) PP. 01-09 DOI 10.35631/AIJBES.37001

source/coronaviruse/situation-reports/20200304-sitrep-44-covid-

19.pdf?sfvrsn=783b4c9d_2

Zaremba, A., Kizys, R., Aharon, D. Y., \& Demir, E. (2020). Infected Markets: Novel Coronavirus, Government Interventions, and Stock Return Volatility around the Globe, Finance Research Letters, Volume 35, 2020, 101597, ISSN 1544-6123. 